\title{
Effect of an integrated control strategy for schistosomiasis japonica in the lower reaches of the Yangtze River, China: an evaluation from 2005 to 2008
}

\author{
Le-Ping Sun ${ }^{1}$, Wei Wang ${ }^{1}$, You-Sheng Liang ${ }^{1 *}$, Zeng-Xi Tian², Qing-Biao Hong ${ }^{1}$, Kun Yang ${ }^{1}$, Guo-Jing Yang ${ }^{1}$, \\ Jian-Rong Dai ${ }^{1}$ and Yang Gao ${ }^{3}$
}

\begin{abstract}
Background: Schistosomiasis japonica remains a major public health concern in China. There are many interventions implemented to control the transmission of the disease. The purpose of the present study was to investigate the effects of an integrated control strategy for schistosomiasis control.
\end{abstract}

Methods: An integrated control strategy for schistosomiasis japonica with emphasis on removing cattle from snailinfested grasslands, providing farmers with mechanized farm equipment, improving sanitation by supplying tap water and building lavatories and latrines and providing boats with fecal-matter containers was implemented in 107 villages of the lower reaches of the Yangtze River, Jiangsu Province, China, during a 32-month period from May 2005 to 2008, and the effectiveness was investigated.

Results: Following the effects of the comprehensive control, the snail habitat, infected snail habitat, snail infection rate, and S. japonicum prevalence in both humans and livestock all appeared a declining trend year by year, with reductions of $47.88 \%, 94.29 \%, 92.55 \%, 96.94 \%$, and $100 \%$ compared with those before the comprehensive control. In addition, all of the 17 counties achieved the infection control in 2007, and 7 reached the criteria of transmission control in 2008. The confirmed snail habitats reduced from 107 to 20, and the acute infections have also been controlled for 2 successive years since 2007.

Conclusions: The integrated control strategy for schistosomiasis japonica is effective to control the transmission of S. japonicum.

Keywords: Schistosomiasis, Schistosoma japonicum, Oncomelania hupensis, Integrated control, Effect evaluation, The Yangtze River

\section{Background}

Human infection by the blood-fluke Schistosoma japonicum (Platyhelminthes: Trematoda) remains a major public health concern in the People's Republic of China, the Philippines, and parts of Indonesia [1-6]. In China, concerted control effects since the 1950s have dramatically reduced the number of the areas endemic for the parasite as well as the burden of disease among humans

\footnotetext{
* Correspondence: wxliangyousheng@yahoo.cn

'Jiangsu Institute of Parasitic Diseases, 117 Yangxiang, Meiyuan, Wuxi

214064, Jiangsu Province, People's Republic of China

Full list of author information is available at the end of the article
}

[7-10]. Nevertheless, in the remaining core endemic regions, mainly located along the middle and lower reaches of the Yangtze River and some mountainous areas of provinces of Yunnan and Sichuan, over 0.7 million people are estimated to be infected, with a further 30 million at risk of infection [11]. And currently in China, more than $80 \%$ of all human S. japonicum infections are concentrated in the marshland and lake regions of Jiangsu, Jiangxi, Anhui, Hunan and Hubei provinces where the interruption of transmission has been proved particularly difficult to be achieved $[12,13]$.

\section{Biomed Central}

(c) 2011 Sun et al; licensee BioMed Central Ltd. This is an Open Access article distributed under the terms of the Creative Commons Attribution License (http://creativecommons.org/licenses/by/2.0), which permits unrestricted use, distribution, and reproduction in any medium, provided the original work is properly cited. 
Jiangsu province is located in the lower reaches of the Yangtze River in the east of China. Following the effect of flood of the upper reaches of the Yangtze River during the annual monsoon season [14,15], the marshlands along the Yangtze River operate in a "winter-land, summer-water" cycle, and vast grass-covered marshlands emerge after floodwaters recede, resulting in ideal breeding sites for Oncomelania hupensis survival and reproduction [16-18]. Historically, Jiangsu province suffered from a high prevalence of schistosomiasis japonica. After more than two decades of active comprehensive control with an emphasis on snail control by means of environmental improvement and mollusciciding, the province achieved the transmission control of the disease in $1976[9,10,19]$. Since the middle 1980s, the global strategy of schistosomiasis control has shifted from transmission control to morbidity control [20], following the development of the highly effective and safe schistosomicidal agent praziquantel $[21,22]$. In Jiangsu province, the praziquantel-based control strategy has been implemented on a large scale in all endemic areas since the late 1980s [23], particularly during the period of World Bank Loan Project for Schistosomiasis Control [24], which resulted in reduced morbidity caused by the parasite [25]. However, following the termination of the World Bank Loan Project for Schistosomiasis Control and the repeated flooding by the Yangtze River in the 1990s $[15,16,19,26,27]$, acute human schistosomiasis cases were detected again and the area inhabited by infected O. hupensis snails started to increase [25,28]. Furthermore, surveillance studies suggest that chemotherapy-based programs, even those in combination with large-scale mollusciciding against snails, are unlikely to have much further impact upon prevalence levels among humans [11,12].

In 2005, the Jiangsu province proposed two goals for schistosomiasis control. First, by 2007, all of the 22 counties that were endemic for S. japonicum reached the criteria for infection control, and more than $50 \%$ of the counties reached the criteria for transmission control or transmission interruption. Second, by 2010, all of the schistosome-endemic counties reached the criteria for transmission control $[29,30]$. To achieve these two targets, since May, 2005, the Jiangsu province, according to the current local schistosomiasis epidemics, implemented an integrated control strategy for schistosomiasis japonica. Particularly emphasized were removing cattle from snail-infested grasslands, providing farmers with mechanized farm equipment, improving sanitation by supplying tap water and building lavatories and latrines, providing boats with fecal-matter containers, and other routine interventions like health education, snail control, and praziquantel-based synchronous chemotherapy for both infected humans and livestock [31].
In the present study, we describe the implementation of the integrated strategy and investigate the effectiveness of the strategy adopted in 107 villages from 17 counties along the lower reaches of the Yangtze River, Jiangsu province, during a 32-month period from May, 2005 to December, 2008.

\section{Methods}

\section{Study area}

A total of 107 villages from 17 counties of Jiangsu province were included in the current study (Figure 1), where S. japonicum-infected snails were detected during the period between March, 2003 and April, 2005. The study areas had a total of 273,533 residents, 1323 bovine (including 971 cattle), 4379 sheep, 142 sluices and 103 river courses. Currently, 319 cases with advanced schistosomiasis were found and 977 cases with chronic schistosomiasis were identified from 2001 to 2005 [32]. From 2003 to April, 2005, a total of 266 sites infested with infected snails were detected in the study areas, with areas of $2877.85 \mathrm{hm}^{2}$.

\section{Interventions to control sources of S. japonicum infection} During the study period from May, 2005 through 2008, considering that cattle were identified as the primary source of S. japonicum [33,34], all the 971 cattle were replaced with small farm machines to eliminate cattle as a source of infection to snails. And 8554 domestic animals (including bovine, sheep, pigs, dogs) were raised in pens to reduce or avoid the contamination of the grassland. To reduce humans as a source of infection in snails, the following interventions were implemented to attempt to reduce the transmission. A total of 725 households were supplied with tap water, 1907

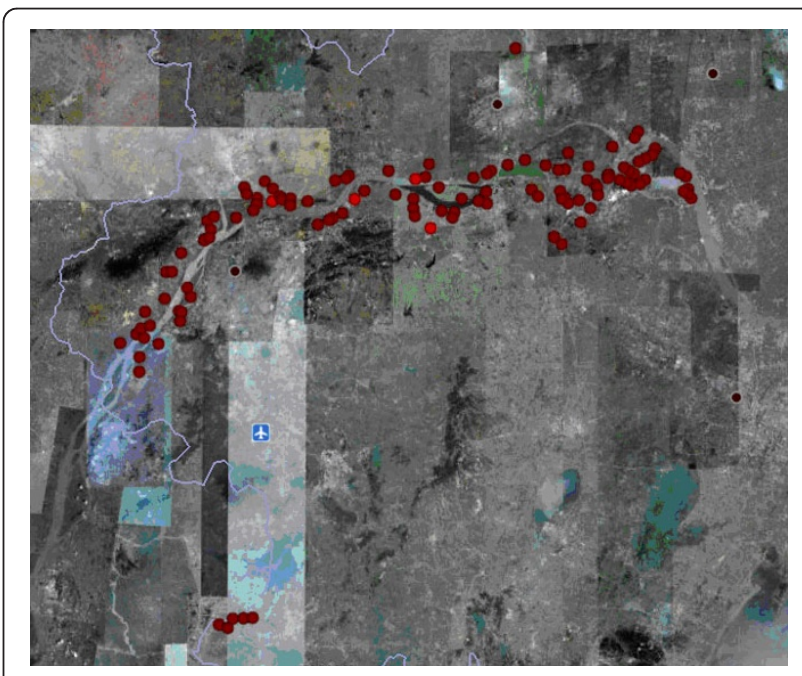

Figure 1 Location of the study villages in the lower reaches of the Yangtze River, Jiangsu province, China. 
fecal-matter container were supplied to the mobile boat fishermen and 75129 public latrines with three-cell septic tanks were constructed, so that human feces could be disposed of on land instead of directly into the lake.

\section{Comprehensive control of snail habitats}

A comprehensive approach was employed to control snails by mollusciciding together with environmental modification. Over the 32-month study period, a total of $12671.52 \mathrm{hm}^{2}$ of snail habitats were treated with molluscicides like niclosamide. Environmental improvement such as constructing fish ponds, digging new ditches, building fruit trees and filling of infested areas was carried out by health sections, together with water resources development and agricultural and forestry projects. During the study period, $4173.55 \mathrm{hm}^{2}$ of snail habitats underwent environmental modification, 44 sluices were re-built for prevention of snail spread, and $217.4 \mathrm{~km}$ long river banks were hardened using concrete.

\section{Other routine control interventions}

During the study period in all villages, some routine control activities were undertaken to control S. japonicum infection. These interventions included synchronous chemotherapy for both infected humans and livestock, and health education focusing on avoidance of snail-infested areas and associated lake water. From 2005 to 2008, 0.21 million people including 3922 boat fishermen were examined for schistosomiasis infections using serological screening with dipstick dye immunoassay (DDIA) [35-37], followed by the miracidium hatching test [32], 7264 high-risk populations were treated with praziquantel at a single oral dose of $40 \mathrm{mg} / \mathrm{kg}$ for expanded chemotherapy, and 0.55 million persons received health education by means of cartoons, videotapes, comic-style booklets, billboards, sessions and other media.

\section{Infection in humans and livestock}

During the period of schistosomiasis non-transmission of each year, more than 90\% of individuals aged 6-60 years in each study village were screened for S. japonicum antibodies using the DDIA technique [35-37], and the miracidium hatching test was employed in those seropositive individuals for definitive diagnosis of infections [32]. The miracidium hatching test was used for detecting infection of S. japonicum in livestock [32]. The seroprevalence and parasitological prevalence of $S$. japonicum were recorded and calculated.

\section{Effect evaluation of snail control}

From 2005 to 2008, once-yearly (from April to May) a snail survey was carried out by means of a systematic sampling technique along the river banks and in marshland and ditches around the study villages [32]. A snail collection device made of iron wire and consisting of a $0.1 \mathrm{~m}^{2}$ square frame was placed every $20 \mathrm{~m}$ along the survey line. All snails within the frame were collected, enumerated, crushed and examined for S. japonicum infection using a microscopy. Various indices were recorded, namely snail habitats, density of living snails, density of infected snails and the snail infection rate.

\section{Ethical approval}

This study was approved by the Ethics Review Committee of Jiangsu Province, Jiangsu Institute of Parasitic Diseases, and National Institute of Parasitic Diseases, Chinese Center for Disease Control and Prevention.

\section{Statistical analysis}

All data were entered in Excel (Microsoft Corporation; Redmond, WA, USA) and all statistical analyses were performed using the statistical software Statistical Package for the Social Sciences Version 13.0 (SPSS Inc., Chicago, IL, USA). Differences of proportions were tested for statistical significance with the chi-square test. A Pvalue $<0.05$ was considered significant.

\section{Results}

\section{S. japonicum infections in humans and livestock}

The prevalences of S. japonicum were $0.57 \%, 0.2 \%$, $0.13 \%, 0.03 \%, 0.01 \%$ and $0.02 \%$, respectively in humans, and $0.4 \%, 0.37 \%, 0.1 \%, 0.04 \%, 0.01 \%$ and 0 in livestock from 2003 to 2008 (Table 1, Figure 2). Between 2003 and 2008, the annual acute infections were 116, 38, 11, 2,0 and 0 , presenting a significant declining trend. After the implementation of the integrated schistosomiasis control strategy, the seroprevalence, parasitological prevalence and prevalence of S. japonicum in humans reduced by $81.17 \%, 90.35 \%$ and $96.94 \%$, respectively, and $100 \%$ of reductions in prevalence of livestock and bovine and acute infections were also achieved (Table 2), in comparison with those rates before the implementation of the integrated strategy (all $P$ values $<0.01$ ).

\section{S. japonicum infections in snails}

From 2003 to 2008, the confirmed snail habitats out of all field survey sites were 80, 90, 60, 44, 41 and 20, respectively. The total area of snail habitats was reduced from $7243.06 \mathrm{hm}^{2}$ to $3775.26 \mathrm{hm}^{2}$, and the area where infected snails were detected decreased from 2173.93 $\mathrm{hm}^{2}$ to $124.19 \mathrm{hm}^{2}$ over the study period. The prevalences of S. japonicum infections in the snails collected from 2003 to 2008 were $0.31 \%, 0.16 \%, 0.13 \%, 0.21 \%$, $0.09 \%$ and $0.02 \%$, respectively (Table 3 ). After the implementation of the integrated strategy, the snail host and S. japonicum infections in snails were controlled 
Table $1 \mathrm{~S}$. japonicum prevalence in humans and livestock and acute infections in the 107 villages in a pilot control program of Jiangsu Province, from 2003 to 2008

\begin{tabular}{|c|c|c|c|c|c|c|c|c|c|c|}
\hline \multirow[t]{2}{*}{ Year } & \multirow[t]{2}{*}{$\begin{array}{l}\text { No. people } \\
\text { examined }\end{array}$} & \multirow[t]{2}{*}{$\begin{array}{l}\text { No. infected } \\
\text { people }\end{array}$} & \multirow[t]{2}{*}{$\begin{array}{l}\text { Prevalence of } \\
\text { residents (\%) }\end{array}$} & \multirow[t]{2}{*}{$\begin{array}{l}\text { No. acute } \\
\text { infections }\end{array}$} & \multicolumn{2}{|c|}{$\begin{array}{l}\text { No. livestock } \\
\text { detected }\end{array}$} & \multicolumn{2}{|c|}{$\begin{array}{l}\text { No. infected } \\
\text { livestock }\end{array}$} & \multicolumn{2}{|c|}{$\begin{array}{l}\text { Prevalence of } \\
\text { livestock (\%) }\end{array}$} \\
\hline & & & & & Total & $\begin{array}{l}\text { In: bovine } \\
\text { detected }\end{array}$ & Total & $\begin{array}{l}\text { Infected } \\
\text { bovine }\end{array}$ & Total & $\begin{array}{c}\text { In: } \\
\text { bovine }\end{array}$ \\
\hline 2003 & 140868 & 802 & 0.57 & 116 & 9849 & 5424 & 39 & 35 & 0.4 & 0.65 \\
\hline 2004 & 237443 & 478 & 0.2 & 38 & 9526 & 4956 & 35 & 15 & 0.37 & 0.3 \\
\hline 2005 & 229979 & 298 & 0.13 & 11 & 15928 & 3900 & 16 & 8 & 0.1 & 0.21 \\
\hline 2006 & 264357 & 90 & 0.03 & 2 & 16170 & 2724 & 6 & 3 & 0.04 & 0.11 \\
\hline 2007 & 305719 & 45 & 0.01 & 0 & 14215 & 2198 & 2 & 2 & 0.01 & 0.09 \\
\hline 2008 & 252323 & 44 & 0.02 & 0 & 13705 & 1604 & 0 & 0 & 0 & 0 \\
\hline
\end{tabular}

significantly, with reductions in snail habitat, infected snail habitat and snail infections of $47.88 \%, 94.29 \%$ and 92.55\%, respectively (Table 2 ).

Up to 2007, all of the 17 counties achieved the infection control. In 2008, 7 out of the 17 counties reached the criteria of transmission control, and S. japonicuminfected snails were eliminated in 60 out of the 117 study villages.

\section{Discussion}

Historically, Jiangsu Province suffered from a very high prevalence of schistosomiasis japonica in China, 10 out of the 13 cities of the province were endemic for $S$. japonicum, with accumulated schistosomiasis cases of more than 2.5 million, and accumulated snail habitats of about 1.5 billion $\mathrm{m}^{2}[7,9,10,38]$. During the past 5 decades, the Jiangsu Provincial government placed a high priority on the control of schistosomiasis and had carried out many control programs. These effective interventions have resulted in substantial reductions in the prevalence of S. japonicum in humans and livestock, and snail and infected snail habitats [28,29]. The remaining core endemic areas were mainly located in the marshlands along the Yangtze River and those rivers that connect with the Yangtze River [39]. In terms of the present schistosomiasis epidemics, how to highlight

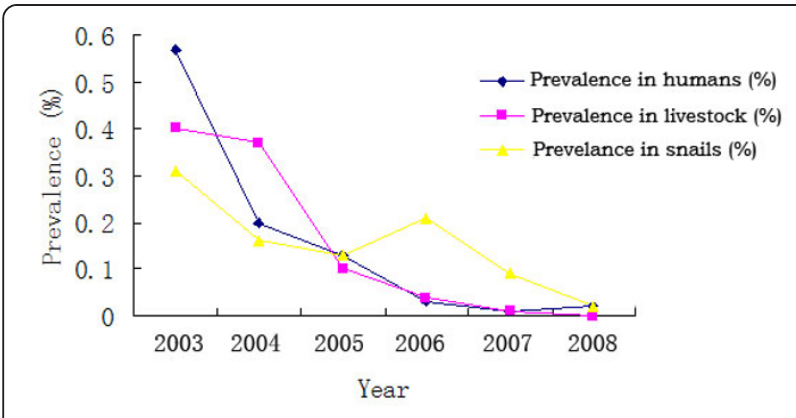

Figure 2 Evolution of average $S$. japonicum prevalence in humans, livestock and $O$. hupensis snails in the study villages from 2003 to 2008 . the control emphasis and then implement the effective interventions is a key point to promote further control programs. In 2004, the Jiangsu Provincial government formulated the Mid- and Long-term Plan for Prevention and Control of Schistosomiasis in Jiangsu Province (2005-2010) based on control of schistosomiasis in Jiangsu section of the Yangtze River, and initiated an integrated control program for schistosomiasis in all villages that are endemic for S. japonicum since 2005 $[31,40,41]$. The strategy focused on 117 villages of the province where $S$. japonicum-infected snails were found. Through the field implementation of the integrated schistosomiasis control, significant control effects were

Table 2 Comparison of the control effects before and after the implementation of the integrated schistosomiasis control strategy in 107 villages of Jiangsu Province

\begin{tabular}{|c|c|c|c|}
\hline Indicator & $\begin{array}{l}\text { Before the } \\
\text { implementation } \\
\text { of the integrated } \\
\text { control strategy }\end{array}$ & $\begin{array}{l}\text { After the } \\
\text { implementation } \\
\text { of the integrated } \\
\text { control strategy }\end{array}$ & $\begin{array}{c}\text { Reductions } \\
\text { (\%) }\end{array}$ \\
\hline $\begin{array}{c}\text { Snail habitats } \\
\left(\mathrm{hm}^{2}\right)\end{array}$ & 7243.03 & 3775.26 & 47.88 \\
\hline $\begin{array}{l}\text { Infected snail } \\
\text { habitats }\left(\mathrm{hm}^{2}\right)\end{array}$ & 2173.93 & 124.19 & 94.29 \\
\hline $\begin{array}{l}\text { No. villages } \\
\text { with infected } \\
\text { snails }\end{array}$ & 80 & 20 & 75 \\
\hline $\begin{array}{l}\text { Seroprevalence } \\
\text { in humans (\%) }\end{array}$ & 4.5 & 0.85 & 81.17 \\
\hline $\begin{array}{l}\text { Parasitological } \\
\text { prevalence in } \\
\text { humans (\%) }\end{array}$ & 0.06 & 0.01 & 90.35 \\
\hline $\begin{array}{l}\text { Prevalence in } \\
\text { humans (\%) }\end{array}$ & 0.57 & 0.02 & 96.94 \\
\hline $\begin{array}{c}\text { Acute } \\
\text { infections }\end{array}$ & 116 & 0 & 100 \\
\hline $\begin{array}{l}\text { Prevalence in } \\
\text { livestock (\%) }\end{array}$ & 0.4 & 0 & 100 \\
\hline $\begin{array}{l}\text { Prevalence in } \\
\text { bovine (\%) }\end{array}$ & 0.65 & 0 & 100 \\
\hline $\begin{array}{l}\text { Snail infections } \\
(\%)\end{array}$ & 0.31 & 0.02 & 92.55 \\
\hline
\end{tabular}


Table 3 Changes of Oncomelania hupensis snail in the 107 villages in a pilot control program of Jiangsu Province, from 2003 to 2008

\begin{tabular}{|c|c|c|c|c|c|c|}
\hline Year & $\begin{array}{c}\text { Snail habitat } \\
\left(\mathrm{hm}^{2}\right)\end{array}$ & $\begin{array}{c}\text { Infected snail habitat } \\
\left(\mathrm{hm}^{2}\right)\end{array}$ & $\begin{array}{l}\text { No. snails } \\
\text { dissected }\end{array}$ & $\begin{array}{l}\text { No. infected } \\
\text { snails }\end{array}$ & $\begin{array}{c}\text { Infection rate of snails } \\
(\%)\end{array}$ & $\begin{array}{l}\text { No. villages with infected } \\
\text { snails }\end{array}$ \\
\hline 2003 & 7243.06 & 2173.93 & 585298 & 1808 & 0.31 & 80 \\
\hline 2004 & 7625.23 & 2130.53 & 597783 & 950 & 0.16 & 90 \\
\hline 2005 & 7701.07 & 1767.70 & 551843 & 705 & 0.13 & 60 \\
\hline 2006 & 5887.96 & 1444.34 & 344905 & 735 & 0.21 & 44 \\
\hline 2007 & 4487.75 & 802.73 & 296868 & 254 & 0.09 & 41 \\
\hline 2008 & 3775.26 & 124.19 & 295384 & 68 & 0.02 & 20 \\
\hline
\end{tabular}

achieved. In addition, the new strategy provided a novel pattern for control of schistosomiasis, namely integrating all kinds of resources and boosting the whole villages.

With the gradual decline of schistosomiasis, the Chinese government has implemented a stratified control pattern based on villages with different intensities of $S$. japonicum infection $[33,34]$. However, the stratification is mainly based on the infection rates of S. japonicum in both humans and livestock, which is increasingly meaningless in areas with low infection intensities [42,43]. Since 2005, we targeted the 107 villages of the province (belonging to 17 counties) where infected snails were detected between March, 2003 and April, 2005, and carried out a comprehensive control strategy for schistosomiasis japonica in the field for a successive four years. Following the effects of the comprehensive control, the snail habitat, infected snail habitat, snail infection rate, and $S$. japonicum prevalence in both humans and livestock all appeared a declining trend year by year, with reductions of $47.88 \%, 94.29 \%, 92.55 \%, 96.94 \%$, and $100 \%$ compared with those before the comprehensive control. In addition, all of the 17 counties achieved the infection control in 2007, and 7 reached the criteria of transmission control in 2008. The confirmed snail habitats reduced from 107 to 20, and the acute infections have also been controlled for a successive 2 years since 2007 . It is indicated that the integrated schistosomiasis control strategy with emphasis on elimination of the snail host could promote the control progress in those regions with low infection intensities.

Schistosomiasis control is a systematic project involving sectors of water conservancy, agriculture, forestry, health, etc [44]. The effects of combination of resources from different sectors on schistosomiasis control remains unclear, and the better utilization would be of great value for further promotion of the control achievements. The present study showed, under the application of the same mollusciciding, the snail habitats kept vast, the prevalence in humans and livestock reduced but still maintained in a high level, and the acute infections were not effectively controlled from 2003 to April, 2005. By contrast, since May, 2005, when the government initiated the integrated control program, the snail habitats reduced dramatically, the prevalence in humans, livestock and snails quickly decreased to a low level, and the acute infections were eliminated. In 2006, a higher snail infection rate was observed compared with those in 2004 and 2005, this was because mollusciciding was not effectively implemented in 1 of 107 villages, leading to a failure in the control of snail control. However, all of the other indicators like the snail habitat, infected snail habitat, number of villages with infected snails, reduced compared with those in both 2004 and 2005.

\section{Conclusions}

The integrated control strategy for schistosomiasis japonica described here is effective to control the transmission of S. japonicum, and it established a new schistosomiasis control pattern that integrates multi-sector resources. Further studies should be carried out to investigate the effects of the strategy in other schistosome-endemic regions of China with comparable ecological, cultural and socio-economic characteristics.

\section{Acknowledgements}

This project received the grants from the National Important Sci-tech Special Projects (2008ZX10004-011), the National Science \& Technology Pillar Program of China (2009BAI78B06 and 2009BAI78B07), the National Natural Science Foundation of China (81071379), Jiangsu Province's Outstanding Medical Academic Leader Program (L201132), the Department of Health Jiangsu Province ( X200912 and X201103), the Jiangsu Provincial Scientific Foundation of Prevention Medicine (Y201031) and Jiangsu Society for Editors of Scientific and Technical Periodicals (JKQJX006).

\section{Author details}

1Jiangsu Institute of Parasitic Diseases, 117 Yangxiang, Meiyuan, Wuxi 214064, Jiangsu Province, People's Republic of China. ${ }^{2}$ Jiangsu Provincial Department of Health, 42 Zhongyang Road, Nanjing 210008, Jiangsu Province, People's Republic of China. ${ }^{3}$ Yangzhou Municipal Center for Disease Control and Prevention, 35 Yanfu East Road, Yangzhou 225002, Jiangsu Province, People's Republic of China.

\section{Authors' contributions}

LPS and YSL conceived and designed the study. LPS collected the data. LPS, WW, ZXT, QBH, GJY, KY, JRD implemented the study. LPS and WW carried out the statistical analysis and prepared the manuscript. YSL revised and finalized the manuscript. All of the authors read and approved the final version of the manuscript. 


\section{Competing interests}

The authors declare that they have no competing interests.

Received: 11 November 2011 Accepted: 30 December 2011

Published: 30 December 2011

\section{References}

1. Engels D, Chitsulo L, Montresor A, Savioli L: The global epidemiological situation of schistosomiasis and new approaches to control and research. Acta Trop 2002, 82:139-146.

2. Chitsulo L, Loverde P, Engels D: Schistosomiasis. Nat Rev Microbiol 2004 2:12-13.

3. Steinmann $\mathrm{P}$, Keiser J, Bos R, Tanner M, Utzinger J: Schistosomiasis and water resources development: systematic review, meta-analysis, and estimates of people at risk. Lancet Infect Dis 2006, 6:411-425.

4. Utzinger J, Bergquist R, Olveda R, Zhou XN: Important helminth infections in Southeast Asia diversity, potential for control and prospects for elimination. Adv Parasitol 2010, 72:1-30.

5. Zhou XN, Bergquist R, Leonardo L, Yang GJ, Yang K, Sudomo M, Olveda R Schistosomiasis japonica control and research needs. Adv Parasitol 2010 72:145-178.

6. Gryseels B, Polman K, Clerinx J, Kestens L: Human schistosomiasis. Lancet 2006, 368:1106-1118

7. Yuan $\mathrm{H}$, Jiang $\mathrm{Q}$, Zhao $\mathrm{G}$, He $\mathrm{N}$ : Achievements of schistosomiasis control in China. Mem Inst Oswaldo Cruz 2002, 97:187-189.

8. Engels D, Wang LY, Palmer KL: Control of schistosomiasis in China. Acta Trop 2005, 96:67-68.

9. Zhou XN, Wang LY, Chen MG, Wu XH, Jiang QW, Chen XY, Zheng J, Utzinger J: The public health significance and control of schistosomiasis in China-then and now. Acta Trop 2005, 96:97-105.

10. Wang LD, Utzinger J, Zhou XN: Schistosomiasis control: experiences and lessons from China. Lancet 2008, 372:1793-1795.

11. Zhou XN, Guo JG, Wu XH, Jiang QW, Zheng J, Dang H, Wang XH, Xu J, Zhu HQ, Wu GL, Li YS, Xu XJ, Chen HG, Wang TP, Zhu YC, Qiu DC, Dong XQ, Zhao GM, Zhang SJ, Zhao NQ, Xia G, Wang LY, Zhang SQ, Lin DD, Chen MG, Hao Y: Epidemiology of schistosomiasis in the People's Republic of China, 2004. Emerg Infect Dis 2007, 13:1470-1476.

12. Zhao GM, Zhao Q, Jiang QW, Chen XY, Wang LY, Yuan HC: Surveillance for schistosomiasis japonica in China from 2000 to 2003. Acta Trop 2005, 96:288-295.

13. Li SZ, Luz A, Wang XH, Xu LL, Wang Q, Qian YJ, Wu XH, Guo JG, Xia G, Wang $L Y$, Zhou XN: Schistosomiasis in China: acute infections during 2005-2008. Chin Med J (Engl) 2009, 122:1009-1014.

14. Dudgeon D, Arthington AH, Gessner MO, Kawabata Z-I, Knowler DJ, Lévêque C, Naiman RJ, Prieur-Richard A-H, Soto D, Stiassny MLJ, Sullivan CA: Freshwater biodiversity: importance, threats, status and conservation challenges. Biol Rev 2005, 81:163-182.

15. Wu XH, Zhang SQ, Xu XJ, Huang YX, Steinmann P, Utzinger J, Wang TP, $\mathrm{Xu}$ J, Zheng J, Zhou XN: Effect of floods on the transmission of schistosomiasis in the Yangtze River valley, People's Republic of China. Parasitol Int 2008, 57:271-276

16. Huang YX, Rong GR, Cai G, Gao ZH, Zhou XN, Zhu YC: Effects of flood on snail distribution in marshland along Yangtze River in Jiangsu Province. Chin J Schisto Control 2000, 12:346-349.

17. Seto EYW, Wu WP, Liu HY, Chen HG, Hubbard A, Holt A, Davis GM: Impact of changing water levels and weather on Oncomelania hupensis hupensis populations, the snail host of Schistosoma jaonicum, downstream of the Three Gorges Dam. Ecohealth 2008, 5:149-158.

18. Zhu HM, Xiang S, Yang K, Wu XH, Zhou XN: Three Gorges Dam and its impact on the potential transmission of schistosomiasis in regions along the Yangtze River. Ecohealth 2008, 5:137-148.

19. Huang YX, Li B, Wang LP, Zhu YC, Zhou XN, Zhao YJ: Evaluation on the disease control effect of World Bank Loan Schistosomiasis Control Project in Jiangsu Province. Chin J Schisto Control 2001, 13:292-295, (in (hinese).

20. WHO: The Control of schistosomiasis. Second Report of the WHO Expert Committee. WHO Tech Rep Ser World Health Organziation, Geneva; 1993, No. 830.

21. Gönnert R, Andrews P: Praziquantel, a new broad-spectrum antischistosomal agent. Z Parasitenkd 1977, 52:129-150.
22. Seubert J, Pohlke R, Loebich F: Synthesis and properties of praziquantel, a novel broad spectrum anthelmintic with excellent activity against schistosomes and cestodes. Experientia 1977, 33:1036-1037.

23. Jiang QW, Wang LY, Guo JG, Chen MG, Zhou XN, Engels D: Morbidity control of schistosomiasis in China. Acta Trop 2002, 82:115-125.

24. Yuan $H$, Jiagang $G$, Bergquist $R$, Tanner $M$, Xianyi $C$, Huanzeng W: The 1992-1999 World Bank Schistosomiasis Research Initiative in China: outcome and perspectives. Parasitol Int 2000, 49:195-207.

25. Hong QB, Sun LP, Huang YX, Li W, Yang K, Gao Y, Zhang LH, Gao Y, Zeng YL, Zhou M, Liang YS, Zhu YC, Cai G: The third sampling survey of schistosomiasis in Jiangsu Province. Chin J Schisto Control 2005, 17:268-272, (in Chinese).

26. Huang $Y X$, Sun $L P$, Hong $Q B$, Gao $Y$, Zhang $L H$, Gao $Y$, Chen $H$, Guo JH, Liang YS, Zhu YC: Longitudinal observation on fluctuation trend of distribution and spread of Oncomelania snails after flood water in marshland of lower reaches of Yangtze River. Chin J Schisto Control 2004, 16:253-256, (in Chinese).

27. Chen XY, Wang LY, Cai JM, Zhou XN, Zheng J, Guo JG, Wu XH, Engels $D$, Chen MG: Schistosomiasis control in China: the impact of a 10-year World Bank Loan Project (1992-2001). Bull World Health Organ 2005, 83:43-48.

28. Hong QB, Huang YX, Cai G, Sun LP, Gao Y, Zhang LH, Gao Y, Liang YS: Surveillance on schistosomiasis in Jiangsu Province from 2000 to 2004. J Path Biol 2007, 2:213-126, (in Chinese).

29. Huang YX, Hong QB, Sun LP, Hang DR, Li W, Zhang JF, Liang YS: Mid-term effectiveness of medium-and-long-term programme of prevention and control of schistosomiasis in Jiangsu Province. Chin J Schisto Control 2008, 20:245-250

30. Sun LP, Liang YS, Wu HH, Tian ZX, Dai JR, Yang K, Hong QB, Zhou XN Yang GJ: A Google Earth-based surveillance system for schistosomiasis japonica implemented in the lower reaches of the Yangtze River, China. Parasit Vectors 2011, 4:223.

31. Wang LD, Chen HG, Guo JG, Zeng XJ, Hong XL, Xiong JJ, Wu XH, Wang XH, Wang LY, Xia G, Hao Y, Chin DP, Zhou XN: A strategy to control transmission of Schistosoma japonicum in China. N Engl J Med 2009, 360:121-128.

32. MOH: Handbook for Schistosomiasis Control Shanghai: Shanghai Science \& Technology Press; 2000, (in Chinese).

33. Wang LD: Key point of schistosomiasis control in China lies in stool management from humans and animals. Chin J Epidemiol 2005, 26:929-930.

34. Wang TP, Vang Johansen M, Zhang SQ, Wang FF, Wu WD, Zhang GH, Pan XP, Ju Y, Ombjerg N: Transmission control of Schistosoma japonicum by humans and domestic animals in the Yangtze River valley, Anhui Province, China. Acta Trop 2005, 96:198-204.

35. Zhu Y, He W, Liang Y, Xu M, Yu C, Hua W, Chao G: Development of a rapid, simple dipstick dye immunoassay for schistosomiasis diagnosis. Immunol Methods 2002, 266:1-5.

36. Zhu Y, Socheat D, Bounlu K, Liang YS, Sinuon M, Insisiengmay S, He W, Xu M, Shi WZ, Bergquist R: Application of dipstick dye immunoassay (DDIA) kit for the diagnosis of schistosomiasis mekongi. Acta Trop 2005, 96:137-141.

37. Xu J, Feng T, Lin DD, Wang QZ, Tang L, Wu XH, Guo JG, Peeling RW, Zhou XN: Performance of a dipstick dye immunoassay for rapid screening of Schistosoma japonicum infection in areas with low endemicity. Parasit Vectors 2011, 4:87.

38. Utzinger J, Zhou XN, Chen MG, Bergquist R: Conquering schistosomiasis in China: the long march. Acta Trop 2005, 96:69-96.

39. Huang YX, Cai G, Wu F, Pao H, Song HT, Zhang XB, Cao SL, Zhu YC: Survey of present situation of marshland and snail habitat areas and study on control strategy of marshland Oncomelania hupensis in 5 cities along the Yangtze River in Jiangsu Province. Chin J Schisto Control 2000, 12:86-90, (in Chinese).

40. Wang LD, Guo JG, Wu XH, Chen HG, Wang TP, Zhu SP, Zhang ZH, Steinmann P, Yang GJ, Wang SP, Wu ZD, Wang LY, Hao Y, Bergquist R, Utzinger J, Zhou XN: China's new strategy to block Schistosoma japonicum transmission: experiences and impact beyond schistosomiasis. Trop Med Int Health 2009, 14:1475-1483.

41. Sun LP, Liang YS, Wu HH, Tian ZX, Hong QB, Huang YX, Gao Y, Mie J, Gao Y, Xie CY, Zhang LH, Wu F, Hu XS: Effect evaluation of 
comprehensive control for schistosomiasis in key villages of Jiangsu Province. Chin J Schisto Control 2009, 21:285-289, (in Chinese).

42. Zhou $X N$, Jiang QW, Sun $L P$, Wang TP, Hong QB, Zhao GM, Wen LY, Yin ZC, Wu XH, Lin DD: Schistosomiasis control and surveillance in China. Chin J Schisto Control 2005, 17:161-165, (in Chinese).

43. Zhou XN, Jia TW, Guo JG, Wang LY, Jiang QW: Management model and its evolution in schistosomiasis control programme of China. Chin J Schisto Control 2010, 22:1-4, (in Chinese).

44. Yuan $\mathrm{H}$ : Achievement and experiences of schistosomiasis control in China. Chin J Epidemiol 1999, 2:3-6, (in Chinese).

doi:10.1186/1756-3305-4-243

Cite this article as: Sun et al: Effect of an integrated control strategy for schistosomiasis japonica in the lower reaches of the Yangtze River, China: an evaluation from 2005 to 2008. Parasites \& Vectors 2011 4:243.

Submit your next manuscript to BioMed Central and take full advantage of:

- Convenient online submission

- Thorough peer review

- No space constraints or color figure charges

- Immediate publication on acceptance

- Inclusion in PubMed, CAS, Scopus and Google Scholar

- Research which is freely available for redistribution

Submit your manuscript at www.biomedcentral.com/submit 